\title{
THE SYSTEM OF COUNTERACTING
}

\section{AND COMBATING TERRORIST FINANCING IN POLAND IN VIEW OF THE EXISTING THREATS}

\author{
Edyta ŻYŁA, MA \\ Faculty of National Security \\ War Studies University, Warsaw, Poland
}

\begin{abstract}
The article includes issues related to counteracting and combating terrorist financing in Poland in the context of existing threats. The regulations in force on the international level, and provisions governing these issues in the Polish legal system are both discussed. Based on data from the General Inspector of Financial Information (Generalny Inspektor Informacji Finansowej), the Ministry of Justice and National Prosecutors' current efforts to combat the practice of the terrorist financing in Poland are summarised. The article shows the potential hazards for terrorist organisations, who use gaps in the Polish system to make attempts to transfer money for criminal practices. One aim of the publication is to attempt to answer the question whether Poland, to a sufficient degree, is prepared for combatting terrorist financing and whether it is able to do it effectively, taking into consideration the scale and character of existing threats.
\end{abstract}

Keywords: combating terrorist financing, money laundering, General Inspector of Financial Information, obliged entities, co-operating units

\section{Introduction}

"Steal the wood from the boiler - cut off your opponent's energy and military strength" - is one of the 36 tricks considered by Chinese military experts from ancient times as key to effective warfare. In spite of the passing of time, this 
principle has not lost anything in topicality and is still as valid today - it is now used to fight terrorism. The leading terrorist organisation, i.e. the Islamic State, has significant financial resources, estimated at \$ 2-4 billion in 2015 (compared to Al Qaeda USD 15-50 million, Hamas USD 70 million, Hezbollah USD 200500 million) (Wojciechowski 2016, pp. 404-405). These funds are used not only for organising terrorist attacks which do not require much financial outlay, but also for the operation of the entire criminal machinery - including propaganda, recruitment, training and political activities. As Sebastian Wojciechowski aptly points out, the Islamic State is a new, yet modern form of terrorist activity, beyond the classic understanding of the terrorist organisation which combines, in a hybrid manner, the features of a criminal group, a state, a terrorist network or a military organization (Wojciechowski 2016, p. 402).

The purpose of the Islamic State and the terrorist organisations supporting it is to create the Great Caliphate, not only in the Middle East but also in the European Union (Wojciechowski 2016, p. 399). This is not, therefore, a conflict of economic interest or territorial ambition - but a civilisational conflict aimed at an open confrontation between Islamic extremism and European culture based on Christianity. Faced with these threats, it is necessary to take decisive action to weaken terrorist organisations. All the more so because the threat to Europe is growing. The Federal Intelligence Service (NDB) believes there is a significant risk that the aggressive struggle for the survival of the caliphate, using all means available, will continue to shift to Europe (Bogdańska 2017). Although the level of threat of terrorism in Poland is currently low, it cannot be considered that our country is free from any terrorist organisation's activities. There is a likelihood of the transfer of financial resources destined for terrorist activities in other countries through Poland or of raising money here for this criminal act (Ministerstwo Spraw Wewnętrznych i Administracji 2016, p. 273).

The most effective method of combatting terrorism is to cut off the organisation from the sources of terrorist funding. The efforts of countries involved in the fight against terrorism and of international and European organisations point in the same direction. This publication will first discuss the key initiatives undertaken at the UN and EU level to weaken the finances of terrorist organisations, especially of the Islamic State. Next, threats from these organisations to our country, the modus operandi of the terrorist funders will be identified, as well as the legal 
framework for counteracting the financing of terrorism in Poland and the principles of organising a system aimed at combatting terrorist financing will be presented. The next part of the publication will discuss some of the terrorist financing schemes, both using the official banking system and through specific Islamic financial instruments, as well as statistical data showing the results of the fight against terrorist financing in Poland.

The purpose of the publication is to identify the threats related to the financing of terrorism and to evaluate, in this respect, the condition of the Polish system of terrorism financing prevention and combat. Therefore, two research problems were formulated: Is Poland sufficiently prepared to fight the financing of terrorism? Given the scale and nature of the current threats, is Poland able to address the phenomenon effectively? The following hypothesis was formed: It appears that the legal status quo and existing institutional settings in Poland are insufficient for effective terrorism financing prevention and combat.

In an attempt to verify the above hypothesis, an analysis of international instruments and Polish regulations setting out the framework for the functioning of the system of counteracting the financing of terrorism was performed. In order to determine the number of analytical investigations which may have been related to the financing of terrorism and conducted by GIIF (General Inspector of Financial Information) over subsequent years, a statistical method was employed.

The statistical method was also used to establish the number of reports submitted by GIIF with ABW, CBŚ, KGP, KG SG, and UKS Warszawa. The analyses demonstrated the extent to which state institutions took actions regarding the counteracting of terrorism financing. The method was further applied to determine the performance of courts and public prosecutor offices in the area of combatting the financing of terrorism.

Another method used in the research was synthesis, which allowed the researcher to draw general conclusions concerning the study issues and to identify the interrelations between individual elements distinguished in the course of the analysis. (Apanowicz 2005).

It is justified to investigate this point, a fortiori, as the scientific world in Poland has given it relatively little attention, despite the fact that counteracting the financing of terrorism is an important prerequisite for ensuring the security of the 
state. As Jerzy Wojciech Wójcik puts it, whereas the scientific world is interested in counteracting money laundering, there is a complete absence of such considerations regarding the question of counteracting the financing of terrorism (Wójcik 2007, pp. 74-75).

Contrary to Poland, however, the issue has been widely covered by the world of science in other countries, in particular in the United States, France, the United Kingdom, and Israel. Due to the nature of legal regulations, involving a concurrent application of anti-money laundering measures and counter terrorist financing activities, typically both phenomena are studied jointly. Interest in the field surged after the attacks on the World Trade Center in 2001. Nonetheless, as indicated by Ehi Eric Esoimeme, these issues had been at the centre of attention of many environments long before the event. By the end of 2000, two international conventions, in which UN Security Council presented mechanisms for identification of terrorist organisations' financial means and indicated how states should freeze them, had been negotiated and presented for conclusion. In addition, soon after the attacks, the Financial Action Task Force issued eight recommendations on combatting money laundering and the financing of terrorism (Esoimeme 2015).

Source literature also includes overviews of individual terrorist organisations and the ways in which they acquire financial means. Colin P. Clarke conducted an analysis of seven such organisations, including Hezbollah, Hamas, Al-Kaida and ISIS. He reviewed not only the background and origins of the entities, but also the scope of their activities, their targets and sources of financing. According to the author, ISIS - considered the richest terrorist organisation - acquires financial means by robbery, extortion, oil trade and smuggling (Clarke 2015).

Among other important research are studies involving special Islamic financial instruments, operating outside the official banking system, the so-called hawala. Given that in Poland, there are few studies concerning the subject area, and in view of the growing risk of terrorist attacks in Europe, this practice should be analysed in detail. Attention should be paid, amongst other things, to a study developed for the U.S. Department of State which looks at the hawala system, its history, and the mechanisms of its application in money laundering (Jost and Sandhu 2000). 
Moreover, the "Monthly Summery of Events" monthly reports issued by the International Institute for Counter-Terrorism (ICT), one of the leading global expert centres, provide interesting data regarding counteracting terrorism, and also in the field related to process financing. ICT is an independent think-tank specialising in the area of security, risk analysis, intelligence materials and defence policy. The above mentioned reports are published periodically on ICT's website http://www.ict.org.il (Landau 2016-2017).

\section{International Initiatives}

The UN Security Council has repeatedly pointed to the threat to international peace and security caused by terrorist organisations marked by the adoption of the following resolutions: 2199 (Resolution 2199 of Security Council 2015), 2249 (Resolution 2249 of Security Council 2015), 2253 (Resolution 2253 of Security Council 2015) and 2255 (Resolution 2255 of Security Council 2015), 2309 in 2016 (dedicated to civil aviation hazards due to potential acts of terror) and 2322. In 2017, Resolution 2341 was devoted to this issue (Resolution 2341 of Security Council 2017).

Resolution No. 2199 adopted on 12 February 2015 listed Islamic terrorist groups in Iraq and Syria, Al-Qaeda and ANF - Front al-Nusra, regarded as Al Qaeda's armed terrorist network in Syria as the main threat to international peace. In this resolution, the Council:

- drew attention to the issue of oil trade with representatives of the above groups and obliged UN Member States to avoid direct or indirect contact with suspicious suppliers;

- obliged UN Member States to take the necessary measures to freeze and block any assets and funds of terrorist groups that can be identified;

- called on the UN Member States to ensure that they would not tolerate, within their jurisdiction, the presence of persons suspected of conducting terrorist activities or supporting such activities. In addition, the UN Member States have been obliged to monitor and supervise the transit and trade routes of such persons or organisations. 
Resolution No. 2249 of 20 November 2015 was devoted primarily to victims of earlier terrorist attacks and was in some way a form of condolence to the victims and families of the attacks that occurred during the whole of 2015 (26 June in Sousse, Tunisia, 10 October in Ankara, 31 October in Sinai, 12 November in Beirut and 13 November in Paris).

Another Resolution, adopted on 17 December 2015 (No. 2253), condemned the Islamic State in Iraq and the Levant and pledged to combat it. It also pointed to the need to combat the physical persons, companies and all other actors who, directly or indirectly, bear joint responsibility for terrorist attacks (Resolution 2253 of Security Council 2015).

In turn, the UN Security Council Resolution 2341 of 13 February 2017 (Resolution 2341 of Security Council 2015) called on the UN Member States to cut off the flows of funds and other financial assets and economic resources to individuals and entities appearing on the ISIL and Al Qaeda sanctions list.

The issue of counteracting terrorist financing is also regulated by legislation adopted at European Union level, among which the Directive (EU) 2015/849 of the European Parliament and of the Council of 20 May 2015 on the prevention of the use of the financial system for the purposes of money laundering or terrorist financing, amending Regulation (EU) No 648/2012 of the European Parliament and of the Council, and repealing Directive 2005/60/EC of the European Parliament and of the Council and Commission Directive 2006/70/EC (European Parliament and of the Council 2015) (commonly referred to as the AML Directive).

The directive introduces key definitions for the systems of countering the financing of terrorism in the Member States, including the beneficial owner, the shell bank, and the financial institution. In addition, it imposes a number of obligations on the Member States, including the effective identification of the beneficial owner, i.e. a natural person who has the right to make decisions on behalf of a legal person who is a client of a financial institution. Until now, identifying such a person was often impossible due to the lack of information about the natural persons carrying out the transaction on behalf of a given entity. The data obtained by the financial institutions as a result of such identification would be kept by the Member States in the relevant registers, so that they could also be accessed by other entities. 
Another important change introduced by the Directive is the obligation to carry out risk analysis at the level of the European Commission and the individual Member States. At present, such analyses are prepared by financial institutions, called obliged entities. The development of risk analyses at national level should facilitate the development of professional expertise at the level of the institutions indicated above (Leńczuk 2016).

\section{The scale of the terrorist threat in Poland}

As mentioned in the introduction to this publication, terrorist threats do not bypass Poland. Although the terror threat level in Poland is considered low, no one can be certain that this situation will not change in the coming years. According to the "Report on the security situation in Poland in 2016", terrorist organisations may treat our country as a place where their logistical backbone can be created and through which their financial resources destined for organising terrorist attacks in Europe can be transferred. In support of this opinion, the authors of this report indicates that in 2016, the National Security Agency (Agencja Bezpieczeństwa Wewnętrznego) identified 18 people who carried out transactions that could be used to finance terrorism (Ministerstwo Spraw Wewnętrznych i Administracji 2016, p. 273). In addition, according to data provided by the General Inspector of Financial Information, in 2015, the General Inspector of Financial Information initiated 41 analytical investigations of transactions potentially related to terrorist financing (Generalny Inspektor Informacji Finansowej 2016), while there were 89 investigations of this type in 2016 (Generalny Inspektor Informacji Finansowej 2017). Most of them concerned transactions carried out by people originating from or operating in countries suspected of supporting terrorism, where terrorist organisations operate or where military activities are carried out. The General Inspector of Financial Information was also interested in transactions conducted by non-residents staying in Poland and concerning the acquisition of documents confirming the stay of foreigners in our country (Ministerstwo Spraw Wewnętrznych i Administracji 2016, pp. 277-278).

The scale of the potential risks can be demonstrated by the data gathered by investigative journalists from the TVN channel and Newsweek who have 
determined that USD 9 million of Russian money was transferred through the Polish banking system in the last few years (2012-2014) (Cieśla and GęsinaTorres 2017, pp. 34-37). The abusive mechanism was called by the journalists the "laundromat operation" from the English word "laundering" (and "money laundering").As they established, the Intradecom Company was involved in this practice. This company received, within a few months in 2013, seven transfers from British companies to its bank accounts at Raiffeisen Bank: Tottenham Management Ltd and Seabon Ltd. These companies were involved in a giant money laundering operation that covered 5,140 companies and 732 banks in 96 countries. Over two years, about 21 billion dollars were laundered. The case was analysed by 61 journalists from 32 countries.

The fact that illegal immigrants using fake documents - visas and passports - resided in our country might be considered a worrying signal. In 2014, the Border Guard Service identified 1,870 such cases. Among the seven people arrested at the time, there was a Polish-Syrian couple who dealt with organising the transfer of illegal immigrants to European countries. In addition, a group of Pakistani nationals appeared in Poland who applied to the Office for Foreigners for temporary residence permits and their identity papers raised doubts as to their authenticity (Izak 2015).

There are also reports from the media about the potential threat posed by organised crime which point to the German Deutsche Bank, operating on the Polish market, which was laundering Russian money. It is estimated that the bank has laundered more than 10 billion dollars in fictitious transactions. For legalising these operations, the bank will have to pay a fine of USD 630 million (Filipczyk 2017).It turned out that for 4 years, the bank carried out so-called mirror transactions in London and New York allowing Russian customers to transfer money from Russia via Deutsche Bank. This was done without the knowledge and consent of the supervisory authorities in Germany, the United States and the United Kingdom.

"Poland may be an important element in the process of legalising funds derived from ISIS's criminal activity", admitted Andrzej Dobrzyniecki-Cartier, a lawyer of the Polish-Arab Chamber of Commerce in Warsaw (Dobrzyniecki-Cartier 2015). As he stressed, this is possible first of all due to the relative ease of opening a bank account in Poland. In addition, according to the "Report on the security situation 
in Poland in 2016", the National Security Agency (Agencja Bezpieczeństwa Wewnętrznego) conducted twelve investigations in connection with the suspicion of terrorist activity in 2016, and also identified 10 people suspected of having committed terrorist offences (Ministerstwo Spraw Wewnętrznych i Administracji 2016, p.274). The number of investigations carried out in this area by the National Security Agency (Agencja Bezpieczeństwa Wewnętrznego) was on a similar level in recent years (2010 - 4 investigations, $2011-5,2012-3,2013-7,2014-5)$, but in 2015-2016, there were 8 investigations, and the same in $2016-17$. The number of suspects increased - in 2015 it was 6 people, in 2016 - 10. In contrast, the charges were brought against 6 people - in 2015, and against 4 - in 2016.

\section{The modus operandi of terrorist funders}

Successful cutting off of funding sources for terrorist organisations is a difficult and complicated operation requiring consistent transnational cooperation. Diverse forms of financing, as well as their transfer, make it difficult to counteract them effectively. Due to ever-changing social and economic systems, terrorist financing schemes change dynamically so that only some of the most frequently occurring mechanisms can be identified.

Jerzy Wojciech Wójcik attempted to describe the modus operandi of terrorist funders (Hanausek 1978, p. 221). As the author indicated, the modus operandi of perpetrators of terrorist acts is related to the planned goals of their activity, whereas the modus operandi of terrorist funders is intended to inspire and facilitate the attacks, and thus is a completely different activity (Wójcik 2007, p. 79).

Money for terrorist activities can come from both legal sources and criminal activity. The first category includes: sale of crude oil and natural gas, operation of phosphate mines, industrial plants, cereal crops, rental of real estate, stock exchange transactions, sponsorship and donations (Wójcik 2007, pp. 90-96).

An important source of terrorist financing is the activity of organised criminal groups that raise money in a criminal manner, and then "launder" it using sophisticated money laundering methods, i.e. the introduction of money from illegal or unreported sources into the official financial circuit. Among the activities 
that bring the most income to criminal organisations are: drug trafficking, murders, kidnapping for the ransom, smuggling of arms, cigarettes, control of prostitution, and credit frauds (Wójcik 2007, pp. 82-83).

As one of the ways of raising funds for terrorist activities, Jerzy Wojciech Wójcik indicates the financial support provided by some states and organisations, including: Saudi Arabia which has supported Islamic terrorist organisations for the last years -30 percent of the 50 Saudi charities that have been identified could be seen as supporting terrorism. Between 1973 and 2000, USD 87 billion was allocated for this purpose (Wójcik 2007, p. 80).

Terrorist organisations use a variety of methods to transfer funds obtained through legal and criminal activity. One of them is the functioning of secret banking systems which operate outside of the official financial circuit and are not subject to taxation. They rely on mutual trust - the capital is entrusted to one person in his own state and recovered from another person outside its borders. The system initially operated on the basis of family relationships, but due to a number of legal restrictions introduced under official banking systems, it also extended to persons within the same terrorist organisation. This has intensified the development of the so-called hawala system (Owczarski 2015).

As Jerzy Wojciech Wójcik pointsout, these techniques do not leave any trace in the form of documentation, because all the "accounting" is concentrated in the hands of two traders, periodically comparing the balance of transfers. The absence of a criminal transaction trace facilitates the activities of an organised criminal group, providing its secret way of operating. (Wójcik 2007, pp. 100-101). These methods are used not only by Islamic terrorist organisations, but also Albanian or Russian-speaking mafias.

The transfer of funds destined for terrorist financing is also channelled through online banking products, especially those offered by e-banks. Due to the intensive development of new technologies, tracking all transactions made via the Internet becomes very difficult. Many legal acts in this area are adopted with significant delay, and only in response to these irregularities.

The functioning of offshore companies in the so-called tax, banking and trade havens remains undoubtedly a serious problem. These are countries or territories whose systems of law allow business activity with very low or even zero taxation 
(Bahrain, Vanuatu, and the Cayman Islands).At the same time, these countries guarantee almost anonymity of their operations, mainly thanks to the farreaching banking secrecy. There are also very liberal rules for creating banks in these countries. Thanks to such conditions, it becomes possible not only to secure (from the point of view of criminals) the placement of illegally acquired money, but also its effective disguising (multiple transfers about which, due to banking secrecy, no one will ever know).Money from tax havens then goes to countries where they are legalised, for example by buying real estate. Proving the criminal origins of money is extremely difficult, sometimes impossible, because the law enforcement agencies of the country, in the absence of any cooperation with institutions located in the tax havens, are not able to prove that the money spent, e.g. on the construction of an office building, had not been earned legally (Żyła 2010).

According to Jerzy Wojciech Wójcik, the possibility of establishing offshore companies in tax havens is a scandal in itself. But their existence is still tolerated. Perhaps because it suits too many interested parties, and perhaps also the economic and political decision-makers (Wójcik 2007, p. 110).

\section{Polish system preventing terrorist financing}

In Poland, the anti-terrorist financing system is linked to counteracting money laundering, i.e. the introduction of money from illegal or unreported sources into the official financial circuit. It operates on the basis of the Act of 16 November 2000 on counteracting money laundering and terrorism financing (Ustawa $\mathrm{z}$ dnia 16 listopada 2000 r. o przeciwdziałaniu praniu pieniędzy oraz finansowaniu terroryzmu, DzUz 2017 r., poz. 1049). This legislative act defines the responsibilities of the General Inspector of Financial Information as well as obliged entities and co-operating units.

According to Article 3 of the aforementioned Act, the government administration authority competent for anti-money laundering and terrorist financing is the minister responsible for public finance, as the chief financial information authority and head of the National Tax Administration, as the General Inspector of Financial Information (Ustawa z dnia 16 listopada 2000 r. o przeciwdziałaniu 
praniu pieniędzy oraz finansowaniu terroryzmu, DzU z 2017 r., poz. 1049, art. 3). The Prime Minister appoints and dismisses the General Inspector of Financial Information, upon the request of the Minister of Finance. The General Inspector of Financial Information performs its tasks with the help of the National Tax Administration's organisational unit which was established for this purpose within the Ministry of Finance.

The General Inspector of Financial Information's aim is to obtain, collect, process and analyse information, and to take action to counter terrorist financing, including:- examining the course of transactions which raised the serious suspicion of the General Inspector of Financial Information:

- stopping the transaction or blocking the account;

- transferring documents justifying the suspicion of committing a crime to competent authorities;

- training personnel of obliged entities in terms of tasks assigned to these entities (Ustawa z dnia 16 listopada 2000 r. o przeciwdziałaniu praniu pieniędzy oraz finansowaniu terroryzmu, DzU z 2017 r., poz. 1049, art. 4).

Obliged entities (such as branches of credit institutions, banks, investment firms, savings and credit cooperatives, bureaux de change, auction houses, foundations, and associations) are obliged to register transactions worth more than EUR 15,000 and all those transactions which are carried out by a number of operations of lesser value which may indicate an action intended to avoid registration (Ustawa $\mathrm{z}$ dnia 16 listopada 2000 r. o przeciwdziałaniu praniu pieniędzy oraz finansowaniu terroryzmu, DzU z 2017 r., poz. 1049, art.8). In addition, obliged entities conduct an ongoing analysis of the transactions carried out and take action whenever a transaction raises doubts as to whether it is linked to money laundering or terrorist financing. The results of these analyses are stored for 5 years (Ustawa $\mathrm{z}$ dnia 16 listopada $2000 \mathrm{r}$. o przeciwdziałaniu praniu pieniędzy oraz finansowaniu terroryzmu, DzU z 2017 r., poz. 1049, art. 8a).

In addition, obliged entities apply financial security measures to their clients whose scope is based on the assessment of money laundering and terrorist financing risks. Financial security measures include, among other things:

- customer identification and verification of identity on the basis of documents or information publicly available;

- taking steps aimed at establishing the beneficial owner; 
- obtaining information about the purpose and the nature of the client's business relationship.

Obliged entities must also implement an internal anti-money laundering and terrorist financing procedure. These institutions are also obliged to provide the General Inspector of Financial Information with information on registered transactions. They must also immediately disclose any transaction information at the General Inspector of Financial Information's request (Ustawa z dnia 16 listopada 2000 r. o przeciwdziałaniu praniu pieniędzy oraz finansowaniu terroryzmu, DzU z 2017 r., poz. 1049, art.11).

The Act also provides for close cooperation with the General Inspector of Financial Information, National Security Agency, Central Anti-Corruption Bureau, the prosecutor and the units reporting to the Minister of Internal Affairs and Administration. These entities inform the General Inspector of Financial Information about all cases of obtaining information indicating suspicion of committing the offences referred to in Article 165a of the Penal Code (financing terrorism) or Article 299 of the Criminal Code (money laundering), or described in the aforementioned provisions, as well as the initiation and termination of the proceedings related to these offences (Ustawa z dnia 16 listopada $2000 \mathrm{r}$. o przeciwdziałaniu praniu pieniędzy oraz finansowaniu terroryzmu, DzU z 2017 r., poz. 1049, art.14). Moreover, the institutions subordinated to the Head of the National Tax Administration shall promptly inform the General Inspector of Financial Information of any circumstances that may indicate the possibility of committing such offences.

It should be added that the Anti-Money Laundering and Terrorist Financing Act was amended in early 2017 in connection with the reform of the tax services which resulted in the creation of the National Tax Administration. The amendment entered into force on 1 March 2017. It did not fundamentally change the way the anti-terrorist financing system operates as it had been built on the basis of FATF recommendations and EU law. The main purpose of the amendment to the Anti-Money Laundering and Terrorist Financing Act was mainly to adjust the provisions governing the exchange of information between the General Inspector of Financial Information and the co-operating units in connection with the creation of the National Tax Administration. 
However, this is not the only amendment that will cover the anti-money laundering and terrorist financing law. During the preparation of this publication, the Council of Ministers accepted the new draft of the Act in relation to the need to implement the Directive (EU) 2015/849 of the European Parliament and of the Council of 20 May 2015 on the prevention of the use of the financial system for the purposes of money laundering or terrorist financing, amending Regulation (EU) No 648/2012 of the European Parliament and of the Council, and repealing Directive 2005/60/EC of the European Parliament and of the Council and Commission Directive 2006/70/EC.

This new draft of the Act includes, among other things:

- granting the status of the obliged entity to entities conducting business activity by tracking services in the area of exchange between virtual currencies and means of payment, exchange between individual virtual currencies, storing identification data, providing customers with access to virtual currency units and using them in accordance with the rules provided for that type of virtual currency;

- introduction of the definition of virtual currencies;

- defining the functioning of the Financial Security Committee as an advisory and decision-making body operating under the General Inspector of Financial Information. The tasks of the Committee will include initiating and undertaking cooperation steps between public administration authorities in the field of countering money laundering and terrorist financing;

- setting out the basic principles for preparing a national assessment of the money laundering and terrorist financing risk - it will be prepared by the General Inspector of Financial Information, and its aim will be to improve the anti-money laundering and terrorist financing system;

- the rules governing the use of financial security measures by the obliged entities, adequate to the identified risk of money laundering or terrorist financing;

- the obligations of the obliged entities related to the identification of the beneficial owner have been defined - the entities will be obliged to identify the beneficial owner and not only to make efforts in this respect (Departament Prawny Ministerstwa Finansów 2017). 


\section{The effects of counteracting and combatting terrorist financing in Poland}

At the outset, it should be noted that the definition of terrorist financing offences and the penalty for committing them are contained in Article 165a of the Penal Code which reads: "the collection, transfer or offering of means of payment, financial instruments, securities, foreign exchange values, property rights or other movable or immovable property intended to finance a terrorist offence or to make them available to organised groups or associations committing such offence or to a person taking part in such a group or relationship shall be subject to the penalty of deprivation of liberty for a term between 2 to 10 years" (Ustawa z dnia 6 czerwca 2000 r. - Kodeks Karny, DzU z 2016 r., poz. 1137).

For the time being, Poland has recorded relatively low rates in the fight against terrorist financing - no conviction was handed down in the years 2009-2015 in relation to Article 165a of the Penal Code. As the Ministry of Justice reported in response to a request for access to public information, in that period "common courts did not conduct criminal proceedings in connection with Article 165a of the Penal Code, and no final convictions have been recorded for the abovementioned offence in the database of the IT system of the National Criminal Register" (Ministerstwo Sprawiedliwości 2017, DSF-II-082-16/17). In 2017, however, one conviction was handed down in connection to Article 165a of the Penal Code (Ministerstwo Sprawiedliwości 2017, DSF-II-082-236/17).

Similar results were achieved by the prosecutor's office - in 2015, it charged four people with Article 165a of the Penal Code, in connection with the suspicion of financing terrorist offences in the Middle East (GIIF 2016). On the other hand, according to information provided by the State Prosecutor's Office, in the years 2009-2014, the prosecutor's office did not conduct proceedings for an offences in connection to Article 165a of the Penal Code; whereas in 2015, two preparatory proceedings on terrorist financing were initiated, and in one of them -4 persons were presented with the charges for activities under Article 165a of the Penal Code. The proceedings ended with a bill of indictment being brought. Court proceedings are currently pending. However, in 2016, three further preparatory proceedings were initiated in connection to Article 165a of the Penal Code which are now in the "in rem" phase (Biuro Prezydialne Prokuratury Krajowej, 
PK IIp 15.2017). In 2017, no charges for activities under Article 165a of the Penal Code were presented and no indictment was brought before the court (Biuro Prezydialne Prokuratury Krajowej, PK IIp 245.2017).

The anti-terrorism financing effects are also illustrated by the following data:

The number of investigations initiated by the General Inspector of Financial Information about transactions that may have been linked to the financing of terrorism

\begin{tabular}{|l|l|l|l|l|l|l|l|}
\hline Year & 2016 & 2015 & 2014 & 2013 & 2012 & 2011 & 2010 \\
\hline Number & 89 & 41 & 20 & 7 & 12 & 15 & 19 \\
\hline
\end{tabular}

Source: Report of the General Inspector of Financial Information on the Implementation of the Act of 16 November 2000 on counteracting money laundering and terrorism financing in the years 2010-2016.

\begin{tabular}{|l|l|l|l|l|l|}
\hline Number of objections sent by the General Inspector of Financial Information to: \\
\hline Year & $\begin{array}{l}\text { National } \\
\text { Security } \\
\text { Agency }\end{array}$ & $\begin{array}{l}\text { Central } \\
\text { Anti- } \\
\text { Corruption } \\
\text { Bureau }\end{array}$ & $\begin{array}{l}\text { Polish Police } \\
\text { Headquarters }\end{array}$ & $\begin{array}{l}\text { Border Guard } \\
\text { Headquarters }\end{array}$ & $\begin{array}{l}\text { Tax Control } \\
\text { Office in } \\
\text { Warsaw }\end{array}$ \\
\hline 2016 & 103 & 2 & 1 & 1 & 1 \\
\hline 2015 & 34 & - & 1 & - & - \\
\hline 2014 & 26 & - & - & - & - \\
\hline 2013 & 9 & - & - & - & - \\
\hline 2012 & 17 & - & - & 4 & - \\
\hline 2011 & 19 & - & - & - & - \\
\hline 2010 & 30 & - & - & - & - \\
\hline
\end{tabular}

Source: Report of the General Inspector of Financial Information on the Implementation of the Act of 16 November 2000 on counteracting money laundering and terrorism financing in the years 2010-2016

In addition, relevant information is provided by the Supreme Audit Office report from the audit carried out in 2015. The audit covered the period from 1 January 2013 to 30 June 2015, and was conducted from 16 September to 31 December 2015. The purpose of the audit was to assess the functioning of the General Inspector of Financial Information in the field of the implementation of the statutory duties as regards counteracting money laundering and terrorist financing. 
The Supreme Audit Office stated that:

- the effectiveness of the control system over entities obliged to record transactions above EUR 15,000 was low - among other things when it comes to the money laundering estimated at PLN 18.2 billion in 2014. Assets in the amount of PLN 1.2 million were secured in criminal proceedings, and property confiscated worth PLN 11.5 million, i.e. 0.07 percent of the estimated amount;

- obliged entities conducted few controls - 17 inspections took place in 2013, 14 in the first half of 2015 and 6 in the first half of 2015. The Supreme Audit Office made a reservation as to the selection of control institutions - at the planning stage, risk and control needs were not analysed;

- governors, presidents and mayors did not effectively control the anti-money laundering and terrorist financing associations.

This was mainly due to the lack of regulation enabling them to effectively supervise associations (Najwyższa Izba Kontroli 2016). The relatively low results in the fight against terrorist financing in Poland may raise doubts as to whether our country was indeed a "green island" free from such threats in the period indicated, or whether the system of combating terrorism was not sufficiently potent. As Jerzy Wojciech Wójcik points out, a large number of obliged entities are not prepared to carry out the statutory tasks, mainly because of an inadequate level of education (Wójcik 2007, p. 343).

Jerzy Wojciech Wójcik based the above opinion on the results of the survey conducted among the employees of the obliged entities. The goal of the survey was to assess the level of knowledge about money laundering, social, economic and criminal effects of this practice, current legal regulations and procedural solutions on how to counteract this phenomenon among the employees of obliged entities. Based on the results of the survey, the author formulated, among other things, the following conclusions:

- the lowest level of knowledge has been demonstrated by all respondents in their responses to questions concerning the new legal status;

- all respondents have a higher level of knowledge about the legal issues rather than the procedural ones;

- bank employees do not have a higher level of legal knowledge than employees of other institutions. The level of knowledge about the regulations in force during the survey was generally low (Wójcik 2007, pp. 344-345). 


\section{Conclusions}

The effective combatting of the financing of terrorism is a difficult task, especially because of the need for permanent transnational cooperation which is not always exemplary due to the divergent international interests of individual states. And every weak link allows terrorist organisations to prepare for attacks and to collect and transfer money for these criminal acts.

Despite the low threat posed by terrorist organisations in Poland, one should not imagine that our country is free of such dangers. This is evidenced both by the findings of the General Inspector of Financial Information indicated in the reports quoted in this publication, but also by the reports of journalists and researchers who have tackled the topic of countering the financing of terrorism. According to this data, so-called "dirty money" has been transferred through Poland and the Polish branches of foreign banks and could be used by terrorist organisations for this purpose. The far-reaching anonymity of bank customers and the desire of their employees to continually attract clients, combined with their relatively weak knowledge and low awareness of the risks, make the financial system in Poland attractive to terrorist organisations and they will want to carry out illegal transactions here.

In an attempt to answer the questions posed in the introduction, we ought to express our doubts regarding the efficiency of the Polish system of counteracting and combatting the financing of terrorism in view of the present threats. A relatively low rate of public prosecutors' investigations and, more importantly, court proceedings, give rise to a presumption that either the level of risk in Poland remains low or the Polish system is unable to effectively combat the phenomenon. Given the number of reports communicated by the General Inspector of Financial Information (GIIF) to the Internal Security Agency (ABW) and the list of analytical procedures conducted thereby, we should reckon that threats involving attempts to finance terrorism by such entities are identified, meaning they actually take place. To identify the reasons why said actions are not translated into effects in the form of prosecutors' investigations and court sentences would require additional research; to conduct such research is now a challenge facing the world of science. 
Furthermore, we must note that any attempt to address the question whether the Polish system of counteracting and combatting the financing of terrorism is suitably prepared to face the present-day dangers should include prospective changes in law, such as the new act on counteracting money laundering and the financing of terrorism. Needless to say, such regulations will seal the system, e.g. by defining responsibilities of institutions obliged to identify real beneficiaries or by implementing provisions regarding virtual currencies. The obligation to make risk assessments, which will allow one to take up adequate financial security measures, will beyond any doubt constitute another improvement. Hence, we may assume that changes in law in a few-year perspective will enhance the described system's performance.

The improvement of the system would probably have a positive impact on greater interest in this area from the scientific world. Developing common solutions, based on the experiences of other states and the recommendations of institutions set up to counter the financing of terrorism, would probably have a positive impact on the condition of the Polish system.

\section{References}

Apanowicz, J., 2005. Metodologiczne uwarunkowania pracy naukowej. Difin, Warszawa.

Biuro Prezydialne Prokuratury Krajowej, 2017. Odpowiedź na wniosek o udostępnienie informacji publicznej z dnia 26 stycznia 2017 r. (PK IIp 15.2017).

Biuro Prezydialne Prokuratury Krajowej, 2017. Odpowiedź na wniosek o udostępnienie informacji publicznej z dnia 30 sierpnia 2017 r. (PK IIp 245.2017).

Bogdańska, K., 2017. Raport wywiadu: należy oczekiwać kolejnych ataków IS w Europie. [online]. Available from:http://wiadomosci.wp.pl/raport-wywiadu-nalezy-oczekiwackolejnych-atakow-is-w-europie-6118258464843905a Accessed 2 May 2017].

Cieśla, W. and Gęsina-Torres, E., 2017. Operacja Laundromat, Newsweek, 13.

Clarke, C., P., 2015. Terrorism. In The Financing of Terrorism, Insurgency, and Irregular Warfare. Praeger Security International, USA.

Departament Prawny Ministerstwa Finansów, 2017. Projekt nowelizacji ustawy o przeciwdziałaniu praniu pieniędzyi finansowaniu terroryzmu. [online]. Available from: https://legislacja.rcl.gov.pl/docs//2/12298001/12431396/12431397/dokument286998. pdf [Accessed 4 May 2017]. 
Dobrzyniecki-Cartier, A., 2015. Jak w Polsce ISIS pierze pieniądze. [online]. Available from: http://przestepczosc-gospodarcza.pl/andrzej-dobrzyniecki-cartier/jak-w-polsce-isispierze-pieniadze/ [Accessed 23 Nov 2015].

Esoimeme, E., E., 2015. The Risk-Based Approach to Combating Money Laundering and Terrorist Financing. Eric Press, USA.

Filipczyk, P, 2017. Niemiecki bank prał rosyjskie pieniądze. [online]. Available from: http://wgospodarce.pl/informacje/33218-niemiecki-bank-pral-rosyjskie-pieniadze [Accessed 1 Feb 2017].

Generalny Inspektor Informacji Finansowej, 2016. Sprawozdanie z realizacji ustawy z dnia 16 listopada 2000 r. o przeciwdziałaniu praniu pieniędzy oraz finansowaniu terroryzmu w 2015 r. [online]. Available from: www.mf.gov.pl [Accessed 15 Mar 2016].

Generalny Inspektor Informacji Finansowej, 2017. Sprawozdanie z realizacji ustawy z dnia 16 listopada 2000 r. o przeciwdziałaniu praniu pieniędzy oraz finansowaniu terroryzmu w 2016 r. [online]. Available from: www.mf.gov.pl [Accessed 15 Mar 2016].

Hanausek, T., 1978. Modus operandi i alibi - ewolucja znaczenia pojęć. SKKiP, 8.

Izak, K., 2015. Dokumenty w rękach Państwa Islamskiego. PWPW Człowiek i Dokumenty, 38, July - September.

Jost, P., M. and Sandhu, H., S., 2000. The hawala alternative remittance system and its role in money laundering. Interpol General Secretariat and United States Department of the Treasury Financial Crimes Enforcement, Lyon.

Landau, E., 2016-2017. Monthly Summary of Events. International Institute for CounterTerrorism (ICT), [online]. Available from: http://www.ict.org.il [Accessed 15 Mar 2016].

Leńczuk, J., 2016. VI Dyrektywa: Jak Unia walczy z terroryzmem i praniem brudnych pieniędzy. [online]. Available from:http://www.rp.pl/Opinie/303169970-VI-DyrektywaJak-Unia-walczy-z-terroryzmem-i-praniem-brudnych-pieniedzy.html\#ap-1 [Accessed 16 Mar 2016].

Ministerstwo Sprawiedliwości, 2017. DSF-II-082-16/17, Odpowiedź na wniosek o udostępnienie informacji publicznej Departamentu Strategii i Funduszy Europejskich w Ministerstwie Sprawiedliwości z dnia 18 stycznia 2017 r.

Ministerstwo Sprawiedliwości, 2017. DSF-II-082-236/17, Odpowiedź na wniosek o udostępnienie informacji publicznej Departamentu Strategii i Funduszy Europejskich w Ministerstwie Sprawiedliwości z dnia 23 sierpnia 2017 r.

Ministerstwo Spraw Wewnętrznych i Administracji, 2016. Raport o stanie bezpieczeństwa w Polsce w 2016 r., www.mswia.gov.pl, Warszawa.

Najwyższa Izba Kontroli, 2016. System przeciwdziałania praniu pieniędzy oraz finansowaniu terroryzmu, raport pokontrolny. Warszawa. 
Owczarski, B., 2015. System hawala $i$ finansowanie terroryzmu. [online]. Available from: http://www.nowastrategia.org.pl/system-hawala-i-finansowanie-terroryzmu/ [Accessed 4 Aug 2015].

Resolution 2199 of Security Council, 2015, Threats to international peace and security caused by terrorist acts, Adopted by the Security Council at its 7379th meeting, on 12 February 2015 (Rezolucja Rady Bezpieczeństwa ONZ nr S/RES/2199 (2015) z dnia 12 lutego 2015 r., [online]. Available from: http://www.un.org/en/ga/search/view_doc. asp?symbol=S/RES/2199\%20\%282015\%29 [Accessed 16 Mar 2016].

Resolution 2341 of Security Council, 2017, 'Threats to international peace and security caused by terrorist acts', Adopted by the Security Council at its 7882nd meeting, on 13 February 2017 (Rezolucja Rady Bezpieczeństwa ONZ nr S/RES/2341 (2017) z dnia 13 lutego 2017 r.), [online]. Available from: http://www.un.org/en/ga/search/view_ doc.asp?symbol=S/RES/2341\%282017\%29 [Accessed 16 Mar 2016].

Resolution 2249 of Security Council, 2015, 'Threats to international peace and security caused by terrorist acts', Adopted by the Security Council at its 7565th meeting, on 20 November 2015 (Rezolucja Rady Bezpieczeństwa ONZ nr S/RES/2249 (2015) z dnia 20 listopada 2015 r.). [online]. Available from: http://www.un.org/en/ga/search/ view_doc.asp?symbol=S/RES/2249\%282015\%29 [Accessed 17 Mar 2016].

Resolution 2253 of Security Council, 2015, 'Threats to international peace and security caused by terrorist acts', Adopted by the Security Council at its 7587th meeting, on 17 December 2015 (Rezolucja Rady Bezpieczeństwa ONZ nr S/RES/2253 (2015) z dnia 17 grudnia 2015 r.) [online]. Available from: http:/www.un.org/en/ga/ search/ view_doc.asp?symbol=S/RES/2253\%282015\%29 [Accessed 17 Mar 2016]. ("Reaffirming that terrorism in all forms and manifestations constitutes one of the most serious threats to peace and security and that any acts of terrorism are criminal and unjustifiable regardless of their motivations, whenever, wherever, and by whomsoever committed, and reiterating its unequivocal condemnation of the Islamic State in Iraq and the Levant (ISIL, also known as Da'esh), Al-Qaida, and associated individuals, groups, undertakings, and entities for ongoing and multiple criminal terrorist acts aimed at causing the deaths of innocent civilians and other victims, destruction of property, and greatly undermining stability").

Resolution 2255 of Security Council, 2015, 'Threats to international peace and security caused by terrorist acts', Adopted by the Security Council at its 7590th meeting, on 21 December 2015 (Rezolucja Rady Bezpieczeństwa ONZ nr S/RES/2255 (2015) $\mathrm{z}$ dnia 21 grudnia $2015 \mathrm{r}$.)

Ustawa z dnia 6 czerwca 2000 r. - Kodeks Karny, DzU z 2016 r., poz. 1137.

Ustawa z dnia 16 listopada 2000 r. o przeciwdziałaniu praniu pieniędzy oraz finansowaniu terroryzmu, DzU z 2017 r., poz. 1049. 
Wojciechowski, S., 2016. Terroryzm - stare i nowe dylematy. Rocznik Strategiczny, 1015/16. Instytut Stosunków Międzynarodowych, Uniwersytet Warszawski, Wydawnictwo Naukowe Scholar, Warszawa.

Wójcik, J.,W., 2007. Przeciwdziatanie finansowaniu terroryzmu. Oficyna Wolter Kluwer business, Warszawa.

Żyła, E., 2010. Kodyfikacja prania pieniędzy w polskim i międzynarodowym systemie prawnym z uwzględnieniem efektywności zwalczania tej przestępczości w Polsce. Praca podyplomowa, Uniwersytet Warszawski. 